\title{
Collagen Nanofiber on Titanium or Partially Stabilized Zirconia by Electrospray Deposition
}

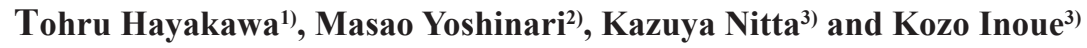 \\ 1) Department of Dental Engineering, Tsurumi University School of Dental Medicine, 2-1-3 Tsurumi, Tsurumi-ku, Yokohama 230-8501, \\ Japan. \\ 2) Division of Oral Implants Research, Oral Health Science Center, Tokyo Dental College, 1-2-2 Masago, Mihamaku, Chiba 261-8502, \\ Japan. \\ 3) Fuence Co., Ltd., 207 Wako RIKEN Incubation Plaza, 2-3-13 Minami, Wako-shi, Saitama 351-0104, Japan.
}

(Accepted for publication, January 29, 2010)

\begin{abstract}
The present study demonstrated collagen nanofiber deposition onto titanium and partially stabilized zirconia, yttria-stabilized zirconia (Y-TZP), using an electrospray deposition (ESD) technique. Type I collagen was dissolved into 1,1,1,2,2,2-hexafluoro-2-propanol at different concentrations. The effects of the flow rate of the collagen solution and the applied voltage on collagen nanofiber deposition were investigated.

For titanium substrates, a collagen concentration of $50 \mathrm{mg} / \mathrm{ml}$, a flow rate of $5.0 \mu \mathrm{l} / \mathrm{min}$, and an applied voltage of $16 \mathrm{kV}$ were found to be suitable for the deposition of uniform collagen nanofibers. Collagen nanofibers could be sprayed onto Y-TZP, which is not an electrically conductive substrate, although nanofibers fused during ESD. To avoid the fusion of nanofibers, titanium sputter-coating was performed on Y-TZP. Less fusion of collagen fibers occurred. A collagen concentration of $50 \mathrm{mg} / \mathrm{ml}$, a flow rate of $5.0 \mu 1 / \mathrm{min}$, and an applied voltage of $25 \mathrm{kV}$ were found to be appropriate for the deposition of uniform collagen nanofibers onto titanium sputter-coated Y-TZP. The ESD technique was shown to be effective for the deposition of collagen nanofibers.
\end{abstract}

Key Words: Collagen nanofiber, Electrospray deposition, Titanium, Partially stabilized zirconia

\section{Introduction}

Titanium and titanium alloys are widely used for dental and orthopedic implants, and various kinds of surface modifications, such as blasting or calcium phosphate coating, were reported to improve the bone response to titanium implants ${ }^{1-3)}$.

It is predicted that the coating of titanium surfaces using celladhesive proteins enhances the cell activity or initial cell attachment around titanium implants, resulting in improved osteoconductivity. Recently, we developed a new technology for the immobilization of cell-adhesive proteins, namely, the tresyl chloride activation technique ${ }^{4.5)}$. Previous study demonstrated that the immobilization of cell-adhesive proteins such as fibronectin or collagen onto titanium using the tresyl chloride method enhanced cell attachment, provided more spread morphologies of attached cells, and altered the gene expression profile ${ }^{6,7)}$.

The electrospray deposition (ESD) method is a technique that involves spraying various kinds of solution containing biomacromolecules and/or synthetic polymers and causing them to form nano-sized particles and/or fibers. ESD is a process through

Correspondence to: Dr.Tohru Hayakawa, Department of Dental Engineering, Tsurumi University School of Dental Medicine 2-1-3 Tsurumi, Tsurumi-ku, Yokohama, 230-8501, Japan Tel: +81-45-580-8365 Fax:+81-45-573-9599,E-mail: hayakawa-t@tsurumi-u.ac.jp which a liquid is transformed into a fine mist by the application of a high-voltage electric field to the capillary or syringe. The principle of ESD is shown in Figure 1. The ESD method consists of the following steps: A strong electric field is applied between a polymer solution contained in a glass capillary or syringe and a conductive substrate. When the voltage reaches a critical value, electrostatic forces overcome the surface tension of the solution, charged droplets are sprayed from the tip of the capillary into a dry atmosphere, and the dried droplets finally accumulate on the substrate to form a thin dry film of fine structures such as nano-/ microscaled particles and fibers.

Morozov et al. ${ }^{8-11)}$ deposited proteins by the ESD technique for protein microarrays and reported that the deposited proteins retained their biological properties. Protein films of a-lactalbumin were also deposited on poly(ethylene terephthalate), which was coated with aluminum, by the ESD technique. The response of deposited protein films to calcium ions was monitored as the biological activity of the films ${ }^{12}$. Schouten et al. ${ }^{13)}$ deposited alkali phosphatase (ALP), calcium phosphate, or a combination of ALP and calcium phosphate coatings onto titanium and evaluated the in vivo bone response to different coatings. They concluded that ALP coatings formed by the ESD technique have potential as bone 


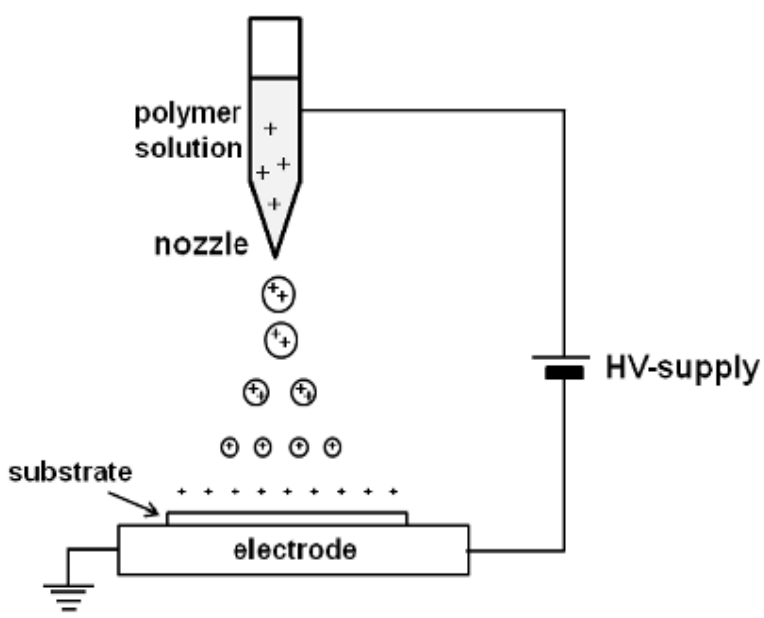

Fig. 1 Schematic drawing of electrospray deposition

implant coatings. Nanofibers of DNA, hyaluronic acid, citrosan, poly(lactic acid) or other synthetic polymers were also prepared by the ESD technique ${ }^{14-17)}$.

As for a biomimetic nanofibrous extracellular matrix for tissue engineering, collagen and/or collagen/apatite and collagen/ poly(glycolic acid) nanofibers were prepared by the ESD technique ${ }^{18-24)}$. Electrospun collagen nanofibers demonstrated cell growth, penetration of cells into the fiber matrix, and enhancement of cell attachment and proliferation ${ }^{18,19)}$. Cells grew not only on the top of the nanofibers but also into them. Collagen/apatite nanofibers increased the mineralization of osteoblast cells ${ }^{21)}$, and collagen/poly(glycolic acid) fibers provided more elongation of adherent cells on fibers with smaller diameters ${ }^{24)}$.

However, there are few reports on the deposition of collagen nanofibers on titanium substrates. It is expected that the deposition of collagen nanofibers on titanium will promote better biological responses, such as the promotion of cell adhesion or bone formation. The aim of the present study was to deposit collagen nanofibers onto titanium substrates using the ESD technique. The effects of collagen concentration and applied voltage between capillary and substrate on nanofiber formation were investigated. In addition to titanium, partially stabilized zirconia, which has recently attracted attention as an esthetic material, was examined as a substrate. The effect of titanium sputter-coating on partially stabilized zirconia was also examined.

\section{Materials and methods}

\section{Materials}

As machined commercially pure titanium (Ti, JIS H4600, 99.9 mass\%, Furuuchi Chemical Co., Tokyo) and yttria-stabilized zirconia (Y-TZP, Toso, Japan) disks with a diameter of $12 \mathrm{~mm}$ and a thickness of $1 \mathrm{~mm}$ were used. Type I collagen (Atelocollagen powder, Koken, Tokyo, Japan) was dissolved into 1,1,1,2,2,2hexafluoro-2-propanol (HFIP, Wako, Osaka, Japan) at concentrations of $100,50,30,15$, and $7.5 \mathrm{mg} / \mathrm{ml}$.

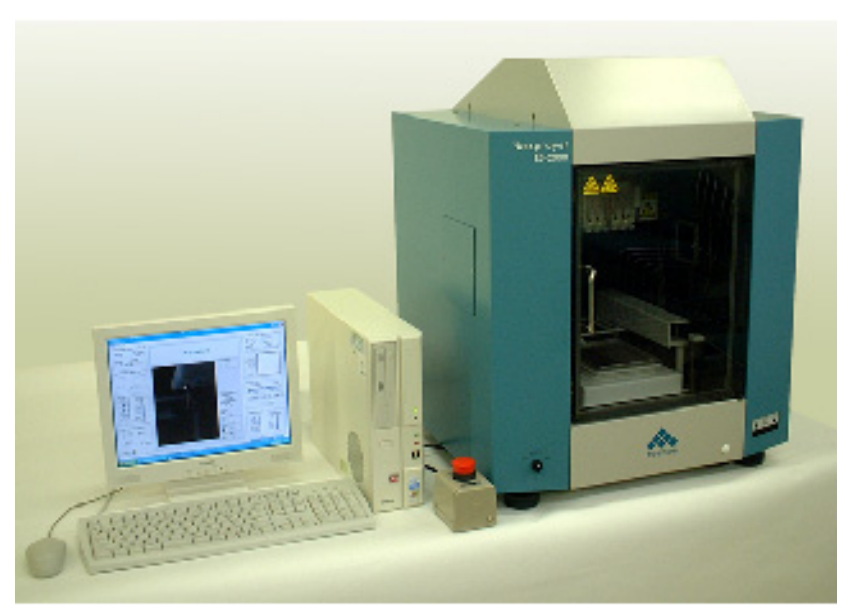

Fig. 2 ESD apparatus used in the present study

Titanium sputter-coating of Y-TZP was performed using an RF magnetron sputter method with a commercially available unit (High Vapor Deposition System, VEP-1000, ULVAC Inc., Kanagawa, Japan) 25). A titanium target (Furuuchi Chemical Co., Tokyo) with a diameter of $52 \mathrm{~mm}$ and a thickness of approximately $5 \mathrm{~mm}$ was used for sputter-coating. The target was bonded to a copper disc plate. The Y-TZP substrate was rotated in a stainless steel chamber ( $300 \mathrm{~mm}$ diameter $\mathrm{x} 500 \mathrm{~mm}$ height) at a rotational velocity of $30 \mathrm{rpm}$. The flow rate of argon gas was $30 \mathrm{sccm}$. The magnetron sputtering was performed using a radio frequency generator operating at $13.56 \mathrm{MHz}$ at a power of 150 watts. The pressure of the chamber was maintained at approximately $0.3 \mathrm{MPa}$. After 10 min of sputtering, nitrogen gas was used to purge the chamber, which was then allowed to return to atmospheric pressure. Titanium sputter-coated Y-TZP (Ti-sputter/Y-TZP) was obtained. The film thickness, determined using a Dektak Stylus Profiler System (stylus force: $25 \mathrm{mg}$, scanning speed: $200 \mathrm{~m} / \mathrm{s}$, Vecco Instrument Inc., Woodbury, NY, USA), was approximately $0.02 \mu \mathrm{m}$.

\section{Electrospray deposition (ESD) of collagen nanofiber}

Electrospray deposition (ESD) was carried out using an ESD device (Fig. 2, ES-2000, Fuence Co., Ltd., Japan). The collagen HFIP solution was sprayed from a glass syringe. The distance between the glass syringe and the substrate surface was $10 \mathrm{~cm}$. The voltage applied between the glass syringe and the substrate was 16 or $25 \mathrm{kV}$, and the flow rate of the collagen HFIP solution was $0.5,1,2$, or $5 \mu \mathrm{l} / \mathrm{min}$. The collagen HFIP solution was electrosprayed for $10 \mathrm{~min}$. The nanofiber spraying was performed in an acrylic chamber under atmospheric conditions. The sprayed collagen nanofibers were then fixed in a vapor of $25 \%$ glutaraldehyde (Wako, Osaka, Japan) at $30{ }^{\circ} \mathrm{C}$ for $5 \mathrm{~min}$. The conditions of the ESD experiments undertaken in the present study are listed in Table 1. The effects of substrate, concentration of collagen, flow rate, and applied voltage were investigated. 

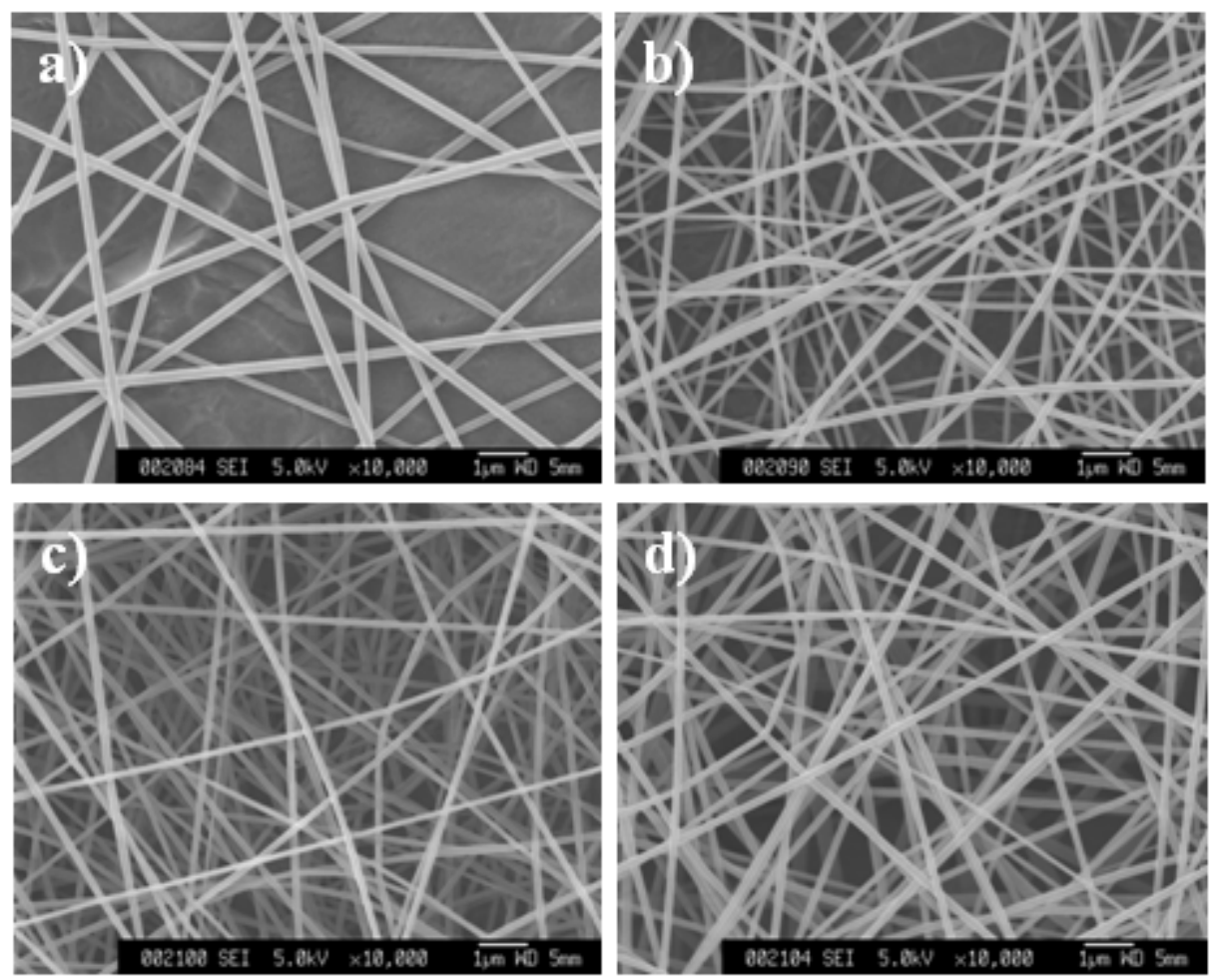

Fig. 3 SEM images of collagen nanofibers sprayed onto titanium using the ESD technique at a collagen concentration of 50 $\mathrm{mg} / \mathrm{ml}$ (Experiment 1). The applied voltage was $16 \mathrm{kV}$.

a) Flow rate of $0.5 \mathrm{ml} / \mathrm{min}$, b) flow rate of $1 \mathrm{ml} / \mathrm{min}$, c) flow rate of $2 \mathrm{ml} / \mathrm{min}$, and d) flow rate of $5 \mathrm{ml} / \mathrm{min}$.

Table 1 ESD conditions for collagen nanofiber deposition

\begin{tabular}{lllll}
\hline Code & Substrate & $\begin{array}{l}\text { Concentration } \\
(\mathrm{mg} / \mathrm{ml})\end{array}$ & $\begin{array}{l}\text { Flow rate } \\
(\mathrm{ml} / \mathrm{ml})\end{array}$ & Voltage $(\mathrm{kV})$ \\
\hline Experiment 1 & titanium & 50 & $0.5,1,2,5$ & 16 \\
Experiment 2 & titanium & 100 & $0.5,1,2,5$ & 16 \\
Experiment 3 & Y-TZP & 50 & 5 & 16,25 \\
Experiment 4 & Y-TZP & $7.5,15,30$ & 5 & 16 \\
Experiment 5 & Ti-sputter/Y-TZP & 50 & 5 & 16,25 \\
Experiment 6 & Ti-sputter/Y-TZP & 30 & 5 & 16,25 \\
\hline
\end{tabular}

After fixation of the collagen nanofibers, the deposited nanofibers were coated with platinum and then the morphologies of nanofibers were observed using a field-emission scanning electron microscope (FE-SEM, JEOL, Tokyo, Japan) at an accelerating voltage of $5 \mathrm{kV}$.

\section{Results}

Figures 3 and 4 show the FE-SEM images of collagen nanofibers sprayed on titanium (Experiments 1 and 2 in Table 1). The effects of collagen concentration $(50 \mathrm{mg} / \mathrm{ml}$, Fig. 3 and 100 $\mathrm{mg} / \mathrm{ml}$, Fig. 4) and flow rate $(0.5,1,2$, and $5 \mu \mathrm{l} / \mathrm{min})$ were first examined. The applied voltage was $16 \mathrm{kV}$. When a collagen concentration of $50 \mathrm{mg} / \mathrm{ml}$ was employed, the diameter of the collagen nanofibers was approximately $200-280 \mathrm{~nm}$ regardless of the differences in the flow rate. A greater flow rate tended to produce denser collagen nanofibers. At a flow rate of $5 \mu \mathrm{l} / \mathrm{min}$, the formation of dense and uniform collagen nanofibers was observed.

When the collagen concentration was increased to $100 \mathrm{mg} / \mathrm{ml}$, the appearance of the fibers that formed was different from that at a collagen concentration of $50 \mathrm{mg} / \mathrm{ml}$. The collagen nanofibers at a concentration of $100 \mathrm{mg} / \mathrm{ml}$ showed a less dense formation than those at $50 \mathrm{mg} / \mathrm{ml}$. The nanofiber diameter increased to approximately $500-700 \mathrm{~nm}$ at a flow rate of $0.5 \mathrm{ml} / \mathrm{min}$, and $200-$ 

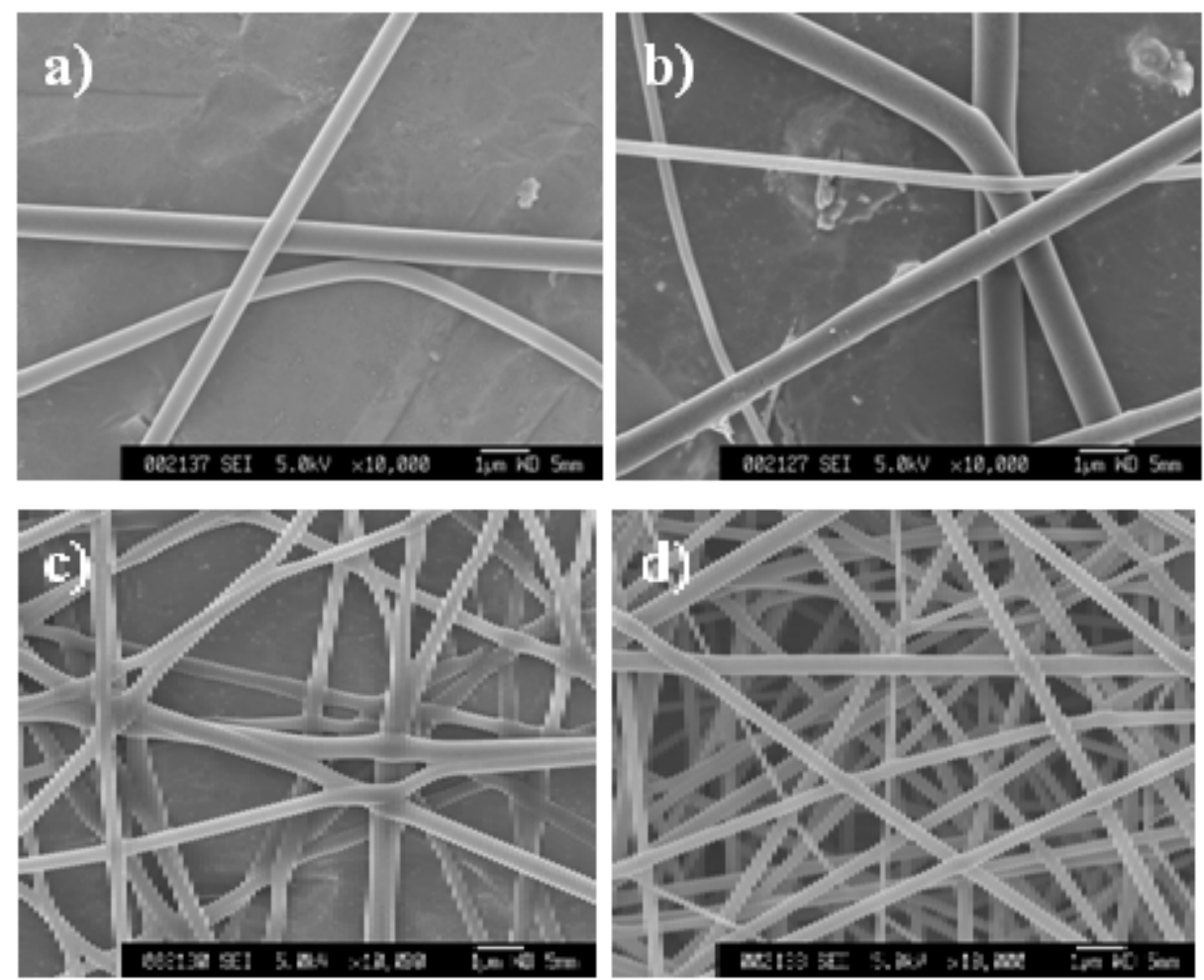

Fig. 4 SEM images of collagen nanofibers sprayed onto titanium using the ESD technique at a collagen concentration of $100 \mathrm{mg} / \mathrm{ml}$ (Experiment 2). The applied voltage was $16 \mathrm{kV}$.

a) Flow rate of $0.5 \mathrm{ml} / \mathrm{min}$, b) flow rate of $1 \mathrm{ml} / \mathrm{min}$, c) flow rate of $2 \mathrm{ml} / \mathrm{min}$, and d) flow rate of $5 \mathrm{ml} / \mathrm{min}$.
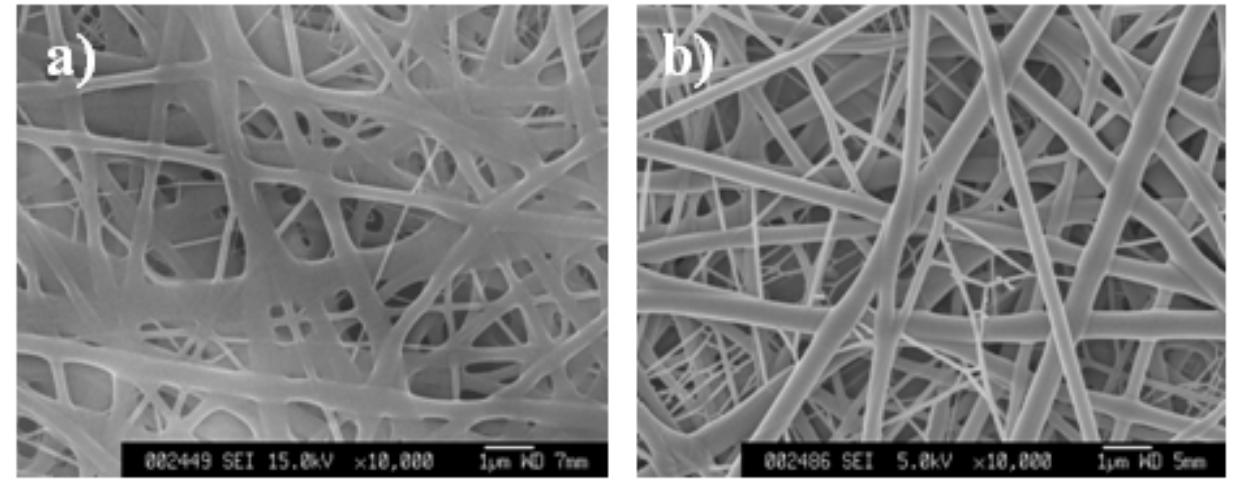

Fig. 5 SEM images of collagen nanofibers sprayed onto Y-TZP using the ESD technique at a collagen concentration of $50 \mathrm{mg} / \mathrm{ml}$ (Experiment 3). The applied voltage was 16 or $25 \mathrm{kV}$ and the flow rate was $5.0 \mathrm{ml} / \mathrm{ml}$. a) Applied voltage of $16 \mathrm{kV}$ and b) applied voltage of $25 \mathrm{kV}$.

$500 \mathrm{~nm}$ at a flow rate of $5.0 \mathrm{ml} / \mathrm{min}$.

The surface appearances of collagen nanofibers deposited onto Y-TZP are shown in Figs. 5 and 6 (Experiments 3 and 4). The collagen concentration was $50 \mathrm{mg} / \mathrm{ml}$ and the flow rate was 5.0 $\mathrm{ml} / \mathrm{min}$. The applied voltage was 16 or $25 \mathrm{kV}$. Although Y-TZP is not an electrically conductive material, collagen nanofibers could be deposited on Y-TZP as shown in Fig. 5. However, the morphology of the collagen sprayed onto Y-TXP was different from that on titanium. Collagen fibers were fused and the fiber diameter was sometimes more than $1000 \mathrm{~nm}$ at $16 \mathrm{kV}$. When the voltage was increased to $25 \mathrm{kV}$, the fusion of collagen fibers was not pronounced compared with that at a voltage of $16 \mathrm{kV}$. The fiber diameter was approximately $600 \mathrm{~nm}$, which was still thicker than that on titanium, and collagen nanofibers deposited on YTXP were less straight and nanofiber spraying was less uniform than on titanium.

Then, collagen concentration was decreased in order to avoid the fusion of sprayed collagen fibers. The voltage was $16 \mathrm{kV}$. When the collagen concentration was $30 \mathrm{mg} / \mathrm{ml}$, less fusion of collagen fibers was observed. At a concentration of $15 \mathrm{mg} / \mathrm{ml}$, 

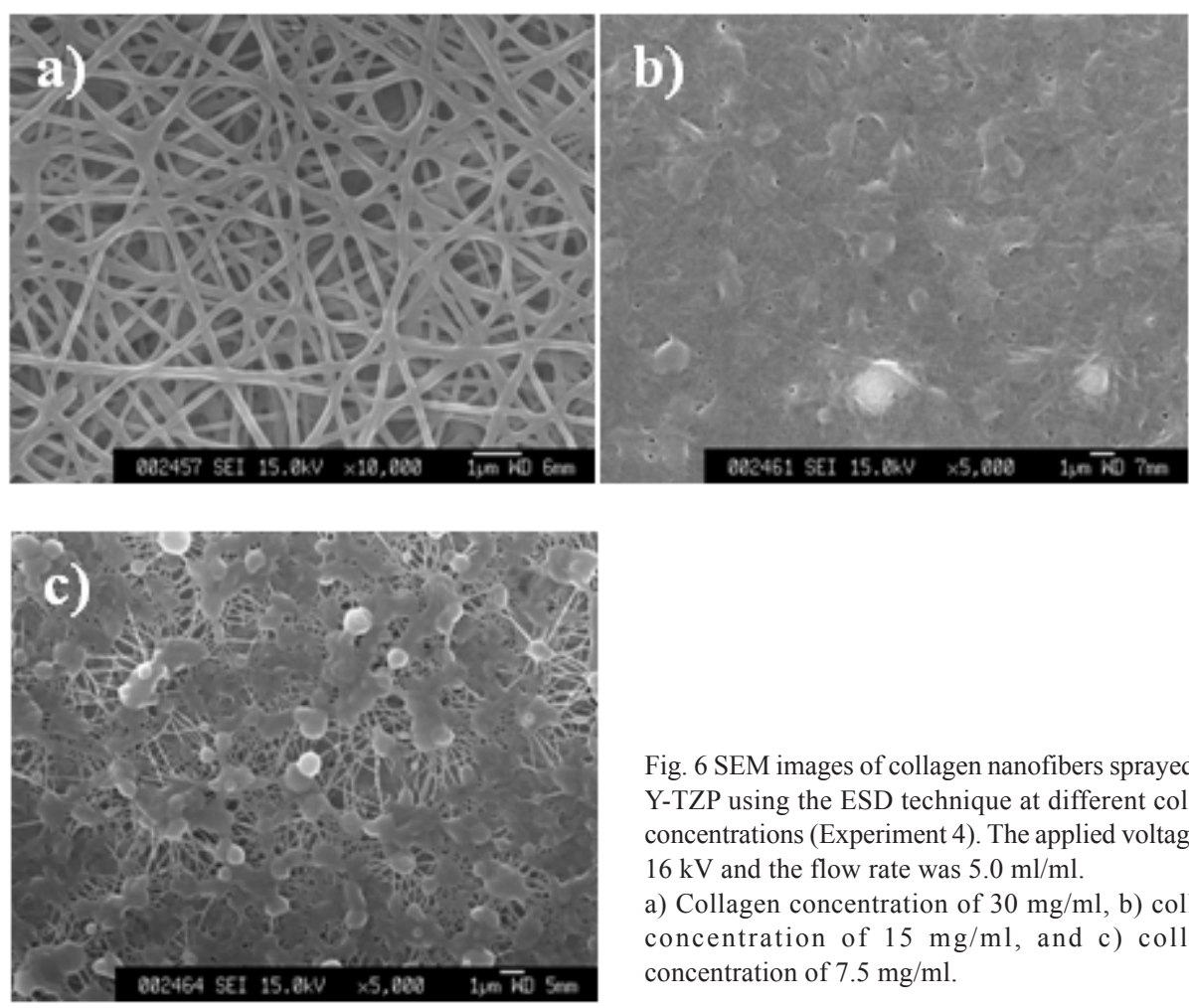

Fig. 6 SEM images of collagen nanofibers sprayed onto Y-TZP using the ESD technique at different collagen concentrations (Experiment 4). The applied voltage was $16 \mathrm{kV}$ and the flow rate was $5.0 \mathrm{ml} / \mathrm{ml}$.

a) Collagen concentration of $30 \mathrm{mg} / \mathrm{ml}, \mathrm{b}$ ) collagen concentration of $15 \mathrm{mg} / \mathrm{ml}$, and c) collagen concentration of $7.5 \mathrm{mg} / \mathrm{ml}$.
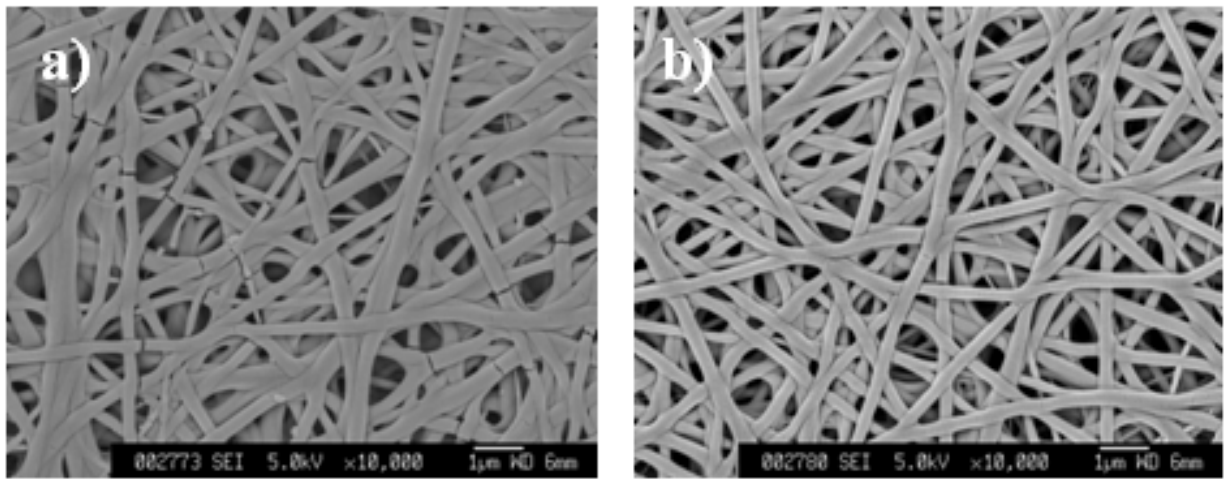

Fig. 7 SEM images of collagen nanofibers sprayed onto titanium sputter-coated Y-TZP using the ESD technique at a collagen concentration of $50 \mathrm{mg} / \mathrm{ml}$ (Experiment 5). The applied voltage was 16 or $25 \mathrm{kV}$ and the flow rate was $5.0 \mathrm{ml} / \mathrm{ml}$. a) Applied voltage of $16 \mathrm{kV}$ and b) applied voltage of $25 \mathrm{kV}$.
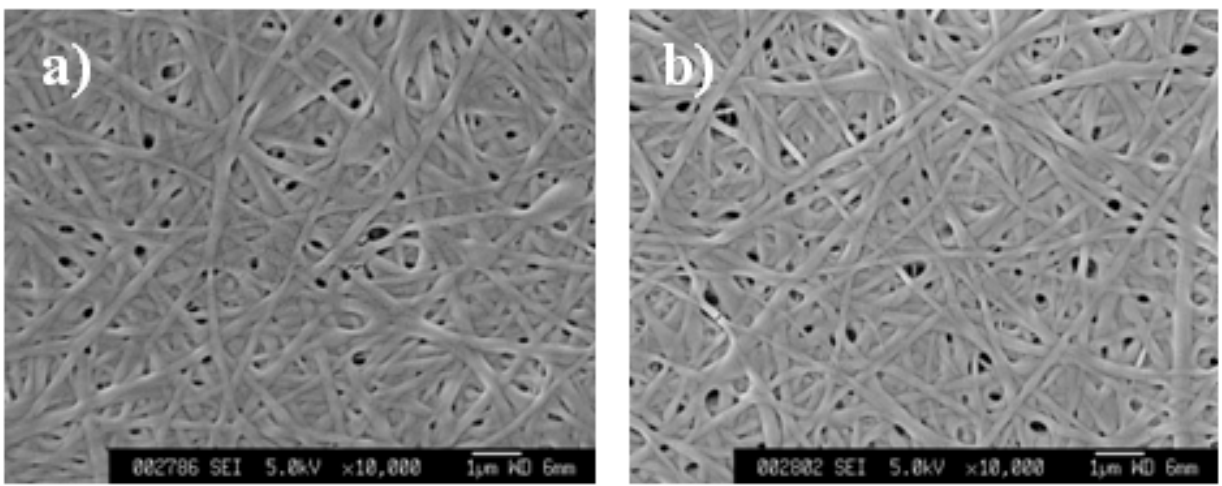

Fig. 8 SEM images of collagen nanofibers sprayed onto titanium sputter-coated Y-TZP using the ESD technique at a collagen concentration of $30 \mathrm{mg} / \mathrm{ml}$ (Experiment 6). The applied voltage was 16 or $25 \mathrm{kV}$ and the flow rate was $5.0 \mathrm{ml} / \mathrm{ml}$. a) Applied voltage of $16 \mathrm{kV}$ and b) applied voltage of $25 \mathrm{kV}$. 
nanofiber formation was not recognized, and a mixture of particles and thin nanofibers was observed at a concentration of $7.5 \mathrm{mg} /$ $\mathrm{ml}$.

Next, collagen nanofibers were sprayed onto Ti-sputter/Y-TZP (Experiment 5 and Experiment 6) as shown in Figs. 7 and 8. Tisputter/Y-TZP was electrically conductive. The collagen concentration was $50 \mathrm{mg} / \mathrm{ml}$ and the flow rate was $5.0 \mathrm{ml} / \mathrm{min}$. The voltage was 16 or $25 \mathrm{kV}$. Nanofiber formation was more pronounced on Ti-sputter/Y-TZP (Fig.7) than on Y-TZP (Fig. 5). However, some fusion of collagen fibers was still observed and the fiber diameter was also greater than that on titanium. Fiber diameter was approximately 400-500 $\mathrm{nm}$. Comparing the results at different applied voltages, a higher voltage was found to produce less fusion of collagen nanofibers on Ti-sputter/Y-TZP than on YTZP. An applied voltage of $25 \mathrm{kV}$ was found to be better for spraying collagen nanofibers onto Ti-sputter/Y-TZP.

When a collagen concentration of $30 \mathrm{mg} / \mathrm{ml}$ was employed, nanofiber formation was not clearly recognized. Fused nanofibers were observed together with deposited collagen films.

\section{Discussion}

In the present study, we deposited collagen nanofibers on titanium or on partially stabilized zirconia using the ESD technique. In the ESD process, the morphologies of the deposited nanofibers can be easily controlled by varying the applied voltage, solution properties such as concentration, viscosity, and surface tension, and the flow rate of the sprayed solution. The effects of collagen concentration, applied voltage, and flow rate of collagen solution on nanofiber formation were investigated. Moreover, the effect of titanium sputter-coating of partially stabilized zirconia substrate was examined.

First, the effects of collagen concentration and flow rate of collagen solution onto titanium substrate were examined. The present study revealed that a collagen concentration of $50 \mathrm{mg} / \mathrm{ml}$ produced more uniform and thinner nanofibers. Concentrations above $100 \mathrm{mg} / \mathrm{ml}$ could not be used for spraying collagen nanofibers during ESD because of the high viscosity of the collagen solution. Matthews et al. ${ }^{18)}$ reported that a concentration of $8 \mathrm{mg} / \mathrm{ml}$ of acid extracts of type I collagen (calfskin) did not result in any fiber formation using the ESD technique. Increasing the concentration of collagen to $83 \mathrm{mg} / \mathrm{ml}$ resulted in the formation of fibers during electrospinning. Further increases in collagen concentration did not grossly alter fiber formation. Rho et al. ${ }^{20)}$ also used a collagen solution with a concentration of $80 \mathrm{mg} / \mathrm{ml}$ for the spraying of nanofibers. Our data suggest that a concentration of $50 \mathrm{mg} / \mathrm{ml}$ is suitable for the spraying of collagen nanofibers, which is close to the reported value of $80 \mathrm{mg} / \mathrm{ml}$.

Low flow rates proved inadequate for the spraying of collagen nanofibers. A flow rate of $5 \mathrm{ml} / \mathrm{min}$ was found to be appropriate for the spraying of collagen nanofibers during ESD.

Partially stabilized zirconia has attracted attention as a material for dental implants because of its esthetic properties and excellent mechanical characteristics ${ }^{26-29)}$. Yttria-stabilized zirconia, Y-TZP, was used as a substrate for collagen fiber deposition in the present study. Y-TZP is a material that is not electrically conductive. In principle, the ESD technique can only be applied for electrically conductive substrates. Electrically charged particles are typically sprayed onto an electrically conductive substrate. However, the present experiment demonstrated that collagen nanofibers could be sprayed onto Y-TZP material using the ESD technique. The thickness of the employed Y-TZP was $1.0 \mathrm{~mm}$. It was speculated that a thickness of $1.0 \mathrm{~mm}$ did not prevent the deposition of electrically charged particles, although the critical thickness for materials that are not electrically conductive was not clear.

However, despite the above development, the fusion of nanofibers was observed. The charged collagen mist fused during spraying before its deposition on the Y-TZP substrate because YTZP is not an electrically conductive material. In order to avoid the fusion of collagen nanofibers, the applied voltage was increased to $25 \mathrm{kV}$ and the collagen concentration was decreased. The increase in applied voltage and the decrease in collagen concentration to $30 \mathrm{mg} / \mathrm{ml}$ produced less fusion of nanofibers, but the formation of nanofibers was less uniform than that on titanium.

Titanium sputter-coating was applied to Y-TZP to improve its electrical conductivity. The effect of titanium sputter-coating was clear. More uniform collagen nanofibers could be sprayed at a concentration of $50 \mathrm{mg} / \mathrm{ml}$ and a voltage of $25 \mathrm{kV}$. Low concentrations did not result in a fiber structure being produced. The coating produced by titanium sputter-coating was very thin, approximately $0.02 \mathrm{~mm}$, so the esthetic property of Y-TZP did not markedly deteriorate.

As a result, collagen nanofibers were determined to be suitable for deposition on not only titanium but also Y-TZP using the ESD technique. A collagen concentration of $50 \mathrm{mg} / \mathrm{ml}$ was found to be suitable for spraying collagen nanofibers. For titanium, an applied voltage of $16 \mathrm{kV}$ is appropriate. On the other hand, an applied voltage of $25 \mathrm{kV}$ is more appropriate for Y-TZP. Titanium-sputter coating was shown to be effective for the spraying of collagen nanofibers onto substrates that are not electrically conductive.

Further research is necessary to evaluate the biological effects of deposited collagen nanofibers by cell assays or animal implantation experiments. The ESD technique is a simple and convenient method for preparing protein nanofibers. Mixtures or laminates of different proteins can also be produced with this technique. It will be possible for other protein nanofibers, such as fibronectin or laminin nanofibers, and mixtures of collagen and fibronectin nanofibers to be sprayed on titanium and/or partially stabilized zirconia using the ESD technique.

\section{References}


Tohru Hayakawa et al.:Collagen Nanofiber by Electrospray Deposition

1. Hayakawa T, Yoshinari M, Nemoto K, Wolke JGC and Jansen JA. Effect of surface roughness and calcium phosphate coating on implant bone response. Clin Oral Impl Res 11: 296-304, 2000

2. Takahashi K, Hayakawa T, Yoshinari M, Hara H, Mochzuki C, Sato M and Nemoto K. Molecular precursor method for thin calcium phosphate coating on titanium. Thin Solid Films 484: 1-9, 2005

3. Hayakawa T, Takahashi K, Yoshinari M, Okada H, Hara H, Yamamoto H, Sato M and Nemoto K. Trabecular bone response to titanium implants provided with a thin carbonatecontaining apatite coating using molecular precursor method. I Int J Oral Maxillofac Implants 21: 851-858, 2006

4. Hayakawa T, Yoshinari M and Nemoto K. Direct attachment of fibronectin to tresyl chloride-activated titanium. J Biomed Mater Res 67A: 684-688, 2003

5. Hayakawa T, Yoshinari M, Nagai M, Yamamoto $M$ and Nemoto K. X-ray Photoelectron spectroscopic studies of the reactivity of basic terminal $\mathrm{OH}$ of titanium towards tresyl chloride and fibronectin. Biomedical Research 24: 223-230, 2003

6. Hayakawa T, Nagai M, Yoshinari M, Makimura M and Nemoto K. Cell-adhesive protein immobilization using tresyl-chloride activation techiniques for the enhancement of initial cell attachment. J Oral Tissue Engin 4: 14-24, 2004

7. Pugdee K, Shibata Y, Yamamichi N, Tsutsumi H, Yoshinari M, Abiko Y and Hayakawa T. Gene expression of MC3T3E1 cells on fibronectin immobilized titanium using tresyl chloride-activation technique. Dent Mater J 26:647-655, 2007

8. Morozov VN and Morozova TYa. Electrospray deposition as a method for mass fabrication of mono- and multicomponent microarrays of biological and biologically active substances. Anal Chem 71: 3110-3117, 1999

9. Avseenko NV, Morozova TYa, Ataullakhanov FI and Morozov VN. Immobilization of proteins in immunochemical microarrays fabricated by electrospray deposition. Anal Chem 15: 6047-6052, 2001

10. Avseenko NV, Morozova TY, Ataullakhanov FI and Morozov $\mathrm{VN}$. Immunoassay with multicomponent protein microarrays fabricated by electrospray deposition. Anal Chem 74: $927-$ 933, 2002

11. Morozov VN, Morozova TY and Johnson KL. Parallel determination of multiple protein metabolite interactions using cell extract, protein microarrays and mass spectrometric detection. Naylor S. Rapid Commun Mass Spectrom 17: 2430-2438, 2003

12. Uematsu I, Matsumoto H, Morota K, Minagawa M, Tanioka A, Yamagata Y and Inoue K. Surface morphology and biological activity of protein thin films produced by electrospray deposition. J Colloid Interface Sci 269: 336340,2004
13. Schouten C, van den Beucken JJ, de Jonge LT, Bronkhorst EM, Meijer GJ, Spauwen PH and Jansen JA. The effect of alkaline phosphatase coated onto titanium alloys on bone responses in rats. Biomaterials 30: 6407-6417, 2009

14. Fang $X$ and Reneker DH. DNA fibers by electrospinning. J Macromol sci B 36: 169-173, 1997

15. Um IC, Fang D, Hsiao BS, Okamoto A and Chu B. Electrospinning and electro-blowing of hyaluronic acid. Biomacromolecules 5: 1428-1436, 2004

16. Nair S, Kim J, Crawford B and Kim SH. Improving biocatalytic activity of enzyme-loaded nanofibers by dispersing entangled nanofiber structure. Biomacromolecules 8: 1266-1270, 2007

17. Wan Y, Cao X, Zhang S, Wang S and Wu Q. Fibrous poly(chitosan-g-DL-lactic acid) scaffolds prepared via electro-wet-spinning. Acta Biomater 4: 876-886, 2008

18. Matthews JA, Wnek GE, Simpson DG and Bowlin GL. Electrospinning of collagen nanofibers. Biomacromolecules 3: 232-238, 2002

19. Li M, Mondrinos MJ, Gandhi MR, Ko FK, Weiss AS and Lelkes PI. Electrospun protein fibers as matrices for tissue engineering. Biomaterials 26: 5999-6008, 2005

20. Rho KS, Jeong L, Lee G, Seo BM, Park YJ, Hong SD, Roh S, Cho JJ, Park WH and Min BM. Electrospinning of collagen nanofibers: effects on the behavior of normal human keratinocytes and early-stage wound healing. Biomaterials 27: 1452-1461, 2006

21. Venugopal J, Low S, Choon AT, Sampath Kumar TS and Ramakrishna S. Mineralization of osteoblasts with electrospun collagen/hydroxyapatite nanofibers. J Mater Sci Mater Med 19: 2039-2046, 2008

22. Ma K, Chan CK, Liao S, Hwang WY, Feng Q and Ramakrishna S. Electrospun nanofiber scaffolds for rapid and rich capture of bone marrow-derived hematopoietic stem cells. Biomaterials 29: 2096-2103, 2008

23. Telemeco TA, Ayres C, Bowlin GL, Wnek GE, Boland ED, Cohen N, Baumgarten CM, Mathews J and Simpson DG. Regulation of cellular infiltration into tissue engineering scaffolds composed of submicron diameter fibrils produced by electrospinning. Acta Biomater 1: 377-385, 2005

24. Tian F, Hosseinkhani H, Hosseinkhani M, Khademhosseini A, Yokoyama Y, Estrada GG and Kobayashi H. Quantitative analysis of cell adhesion on aligned micro- and nanofibers. J Biomed Mater Res A 84: 291-299, 2008

25. Hayakawa T, Yoshinari M, Takahashi $\mathrm{K}$ and Nemoto $\mathrm{K}$. Deposition of thin calcium phosphate film onto titanium using magnetron sputtering method. J Oral Tissue Engin 1: 41-49, 2004

26. Chevalier J. What future for zirconia as a biomaterial? Biomaterials. 27: 535-543, 2006

27. Kollar A, Huber S, Mericske E and Mericske-Stern R. Zirconia 
for teeth and implants: a case series. Int J Periodontics Restorative Dent 28: 479-487, 2008

28. Andreiotelli M, Wenz HJ and Kohal RJ. Are ceramic implants a viable alternative to titanium implants? A systematic literature review. Clin Oral Implants Res 20 Suppl 4:32-47,
2009

29. Blatz MB, Bergler M, Holst S and Block MS. Zirconia abutments for single-tooth implants-rationale and clinical guidelines. J Oral Maxillofac Surg 67: 74-81, 2009 